\title{
Elevated Microparticles, Thrombin-antithrombin and VEGF Levels in Colorectal Cancer Patients Undergoing Chemotherapy
}

\author{
Marek Z. Wojtukiewicz ${ }^{1}$ (D) Marta Mysliwiec ${ }^{1}$ - Ewa Sierko ${ }^{1,2} \cdot$ Monika Sobierska $^{1,3} \cdot$ Joanna Kruszewska $^{1}$. \\ Alina Lipska $^{3}$ • Piotr Radziwon ${ }^{3,4}$. Stephanie C. Tucker ${ }^{5,6} \cdot$ Kenneth V. Honn ${ }^{5,7,8}$
}

Received: 31 May 2020 / Accepted: 11 June 2020 / Published online: 24 June 2020

(C) The Author(s) 2020

\begin{abstract}
Hypercoagulable state and neoangiogenesis are common phenomena associated with malignancy. Cancer patients have increased levels of circulating endothelium-derived microparticles (EMPs), which have been hypothesized to be involved in numerous pathophysiological processes. Hemostasis and angiogenesis are also activated in colorectal cancer (CRC) patients. The study aimed to investigate potential influence of chemotherapy on EMPs, thrombin anti-thrombin complex (TAT) and vascular endothelial growth factor (VEGF) levels in CRC patients undergoing chemotherapy. The study group consisted of $18 \mathrm{CRC}$ patients: 8 stage III colon cancer (CC) and 10 stage IV rectal cancer (RC) patients. EMPs, TAT and VEGF levels were assessed before chemotherapy and after the third course. Results were compared with 10 healthy subjects. EMP concentration was measured by flow cytometry, while TAT and VEGF concentrations were assayed employing ELISA. Compared to the control group, CC and RC patients had significantly higher levels of tissue factor (TF)-bearing and non-TF-bearing EMPs before and after three courses of chemotherapy. VEGF concentrations in CRC patients were higher than in the control groups and increased following chemotherapy. TAT levels were elevated in CRC patients before chemotherapy compared to healthy subjects and significantly increased after the third course of chemotherapy. No significant correlation was found either between EMP and TAT levels, or between EMP concentrations and VEGF levels in the study group. CRC patients have increased EMPs, and TAT as well as VEGF levels tend to increase during chemotherapy.
\end{abstract}

Keywords Endothelium-derived microparticles $\cdot$ Blood coagulation · Angiogenesis $\cdot$ Colorectal cancer

Alina Lipska is deceased.

Marek Z. Wojtukiewicz

mzwojtukiewicz@gmail.com

Marta Mysliwiec

marta.mysl@gmail.com

Ewa Sierko

ewa.sierko@iq.pl

Monika Sobierska

monikasokol84@wp.pl

Joanna Kruszewska

joannak@umb.edu

Alina Lipska

alipska@rckik.bialystok.pl

Piotr Radziwon

piotr.radziwon@wp.pl

Stephanie C. Tucker

stucker@med.wayne.edu
Kenneth V. Honn

k.v.honn@wayne.edu

1 Department of Oncology, Medical University of Bialystok, 12 Ogrodowa St, 15-027 Bialystok, Poland

2 Department of Radiotherapy, Comprehensive Cancer Center, Bialystok, Poland

3 Regional Centre for Transfusion Medicine, Bialystok, Poland

4 Department of Hematology, Medical University of Bialystok, Bialystok, Poland

5 Bioactive Lipids Research Program, Department of Pathology-School of Medicine, Wayne State University, Detroit, MI 48202, USA

6 Karmanos Cancer Institute, 48201 Detroit, MI, USA

7 Department of Chemistry, Wayne State University, 48202 Detroit, MI, USA

8 Department of Oncology, Wayne State University, 48202 Detroit, MI, USA 


$\begin{array}{ll}\text { Abbreviations } \\ \text { CC } & \text { colon cancer } \\ \text { CRC } & \text { colorectal cancer } \\ \text { ELISA } & \text { enzyme-linked immunosorbent assay } \\ \text { EMPs } & \text { endothelium-derived microparticles } \\ \text { RC } & \text { rectal cancer } \\ \text { TAT } & \text { thrombin-antithrombin complex } \\ \text { VEGF } & \text { vascular endothelial growth factor } \\ \text { VTE } & \text { venous thromboembolism }\end{array}$

\section{Background}

Close association between malignancy and blood coagulation disorders has been recognized for over 130 years [1]. Cancer is one of the major independent risk factors for development of venous thromboembolic disease (VTE) [2, 3], which is the second most frequent reason for mortality in cancer patients $[4,5]$. Indeed, cancer patients bear significantly higher (4-7-fold) risk of VTE than their healthy counterparts [6]. The risk of VTE is also increased in colorectal cancer (CRC) patients [7]. Furthermore, oncological therapeutic procedures additionally elevate the risk of thrombosis. Chemotherapy, for example, has been linked to 4.5 to 6-fold incremented risk of VTE [8]. In fact, coagulopathy and angiogenesis are among the most consistent host reactions associated with malignancy.

Most primary tumors and metastatic lesions cannot grow beyond 2 to $3 \mathrm{~mm}^{3}$ in size in the absence of vascularization [9]. Therefore, angiogenesis, a process of new blood vessel formation, is necessary for growth of different types of cancer, including colorectal cancer. There are multiple interactions between coagulation factors of the hemostatic system and angiogenic activity in cancer patients. Various components of the hemostatic system contribute to either promotion or inhibition of angiogenesis and may change a net precarious proangiogenic/ antiangiogenic balance [10]. Tissue factor (TF), which is the main procoagulant, can contribute to tumor angiogenesis via mechanisms that are either dependent on or independent of blood clotting activation (e.g., TF-signaling elevating expression of molecules such as the main proangiogenic factor - vascular endothelial growth factor, VEGF). The procoagulant activity of TF leads to thrombin generation, platelet activation and fibrin formation, all of which influence tumor angiogenesis [11-13]. The expression of both TF [14] and VEGF [15] is controlled by hypoxia. Elevated level of VEGF is a poor prognostic factor in many solid tumors [16].

It has been proven that the level of endothelium-derived microparticles (EMPs) is significantly higher in cancer patients, thereby contributing to blood coagulation activation in this group of patients $[17,18]$. Negatively charged phospholipids expressed on MP are considered to be the main initiators of the coagulation cascade [19]. Additionally, it has been shown that sphingosine 1-phosphate (S1P) strongly potentiates thrombin-induced TF expression in endothelial cells, suggesting its role in blood coagulation. A role for S1P has also been demonstrated in the process of angiogenesis [20], thus explaining why exposed procoagulant phospholipids and specific receptors at the surface of MPs act as biomessengers, linking coagulation and angiogenesis. Endothelium-derived microparticles represent about 10-15\% of the total MPs in plasma of healthy subjects and they can be quantified by flow cytometry using two panels of monoclonal antibodies [21]. EMPs originating from apoptosis are characterized primarily by surface antigen CD31, while EMPs derived from cell activation exhibit increased expression of CD62E antigen [22].

Colorectal cancer patients are known to have higher levels of circulating MPs than healthy controls [23]. Moreover, the population of MPs in CRC patients is highly heterogeneous and some subpopulations may impact blood coagulation and tumor angiogenesis in these patients [24, 25].

The aim of this study was to determine EMP, TAT and VEGF levels in colon cancer patients undergoing adjuvant chemotherapy and in rectal cancer patients undergoing palliative chemotherapy.

\section{Methods}

\section{Study Population}

Blood samples were obtained from eighteen patients (10 males and 8 females) with histopathology-diagnosed G2 adenocarcinoma of colon or rectum. Patients' ages ranged from 41 to 73 years. Depending on the type of chemotherapy, patients were divided into two subgroups. The first subgroup consisted of stage III colon cancer (CC) patients: 4 males and 4 females (aged 44-73) who underwent adjuvant chemotherapy (AC) after surgery. The second subgroup included stage IV rectal cancer (RC) patients with distant metastases: 6 males and 4 females (aged 41-72) who underwent palliative chemotherapy (PC).

After surgery, CC patients received AC according to the FOLFOX regimen. Rectal cancer patients were given first line PC according to the $\mathrm{CLF}_{1}$ regimen, which was a standard therapy in Poland at the time. Targeted therapy was not available at that time in routine clinical settings. Control blood samples were obtained from healthy subjects: 3 males and 7 females aged $40-70$ years.

\section{EMP Enumeration by Flow Cytometry}

The blood was drawn twice from each patient in the study group: before chemotherapy and after the 3rd course of the treatment. In the control group, blood samples were collected once, under the same conditions as in the study group. 
Routinely, $5 \mathrm{ml}$ of blood were collected from the ulnar vein from all patients using a 21 gauge needle into S-Monovette sample tubes (Sarstedt) containing anticoagulant $(0.129$ $\mathrm{mol} / \mathrm{L}$ sodium citrate). Two steps of centrifugation were performed in order to isolate microparticles from whole blood. First, blood samples were centrifuged at $5000 \mathrm{x} g$ at $24^{\circ} \mathrm{C}$ for 5 min without centrifuge brake (removal of blood cells) to prepare platelet-free plasma (PFP). To collect MP, $600 \mu \mathrm{L}$ of PFP were centrifuged at $14000 \mathrm{xg}$ at $20^{\circ} \mathrm{C}$ for $5 \mathrm{~min}$ and the supernatant was removed. The MP pellet was then resuspended in $500 \mu \mathrm{L}$ of diluted Annexin V FITC binding buffer (BD Bioscience, Franklin Lakes, NJ, USA). The storage time of samples never exceeded 30 min following venipuncture, including centrifugation steps.

Quantification of pelleted MP numbers and their phenotypic characterization were conducted by flow cytometry (FACSCalibur, Becton Dickinson, USA). MP size gate was set between 200 and $1000 \mathrm{~nm}$ using fluorescent latex beads 1 $\mu \mathrm{m}$ (Precision Size Standards, Polysciences). The total amount of MP was defined as all events falling within the MP gate. To count the numbers of MP, an aliquot of suspended MP pellet
(100 $\mu \mathrm{L})$ was added to TruCount (Becton Dickinson, USA) (100 $\mu \mathrm{L}$ ), followed by counting up to 2000 of the $0.5 \mu \mathrm{L}$ bead component of TruCount (total absolute count of MP = (events in region except beads/events in region of beads) $\mathrm{x}$ (absolute number of beads/ $\mu \mathrm{L} /$ sample volume $[\mu \mathrm{L}]$ ).

The determination of TF-negative EMPs (TF ${ }^{-}$EMPs) and TF-positive EMPs ( $\mathrm{TF}^{+}$EMPs) was performed employing combination of antibodies: $\mathrm{CD} 31^{+} / \mathrm{CD} 2 \mathrm{E}^{+} / \mathrm{CD} 142^{-} /$ $\mathrm{CD}_{2} \mathrm{~b}^{-}$and $\mathrm{CD}_{1} 1^{+} / \mathrm{CD} 2 \mathrm{E}^{+} / \mathrm{CD} 142^{+} / \mathrm{CD}_{2} 2 \mathrm{~b}^{-}$, respectively, using a BD FACSCalibur flow cytometer (USA). monoclonal antibody anti-CD42b was used to exclude platelet- and megakaryocyte-derived MPs, whereas anti-CD142 was required for TF measurement (Fig. 1).

All monoclonal antibodies used in the study were purchased from Becton Dickinson Pharmingen (San Diego, CA, USA): CD31 stained with FITC, CD62E stained with APC, PE-Cy5 labeled anti-human CD42b, PE labeled anti-human CD142 and kappa isotype control: FITC labeled mouse IgG1, APC labeled mouse IgG, PE-Cy5 labeled mouse IgG1 50, PE labeled mouse $\operatorname{IgG} 1$. The remaining reagents were manufactured by Becton Dickinson Bioscience (San Jose,
Fig. 1 Representative dot plots from the FACSCalibur flow cytometer. Patient's sample. Forward and side scatter of isolated microparticles (MPs). (A) Gated population of all MPs; stained with annexin- $\mathrm{V}$ and using TruCOUNT internal calibrator. The forward scatter cut off was set using $1.0-\mu \mathrm{m}$ standard beads to define the upper limit of MPs population; (B) the MPs gate for Fluorescein isothiocyanate (FITC)-conjugated anti-CD31+; (C) the gate for MPs negative for Peridinin-chlorophyll proteinCy5.5 (PerCP-Cy5.5)-conjugated anti-CD42+; (D) gate (R6) for MPs positive for CD31 + and negative for CD42+; (E) the MPs gate for Allophycocyanin (APC)conjugated anti-62E+; (F) the MPs gate for Phycoerythrin (PE)conjugated anti-142+
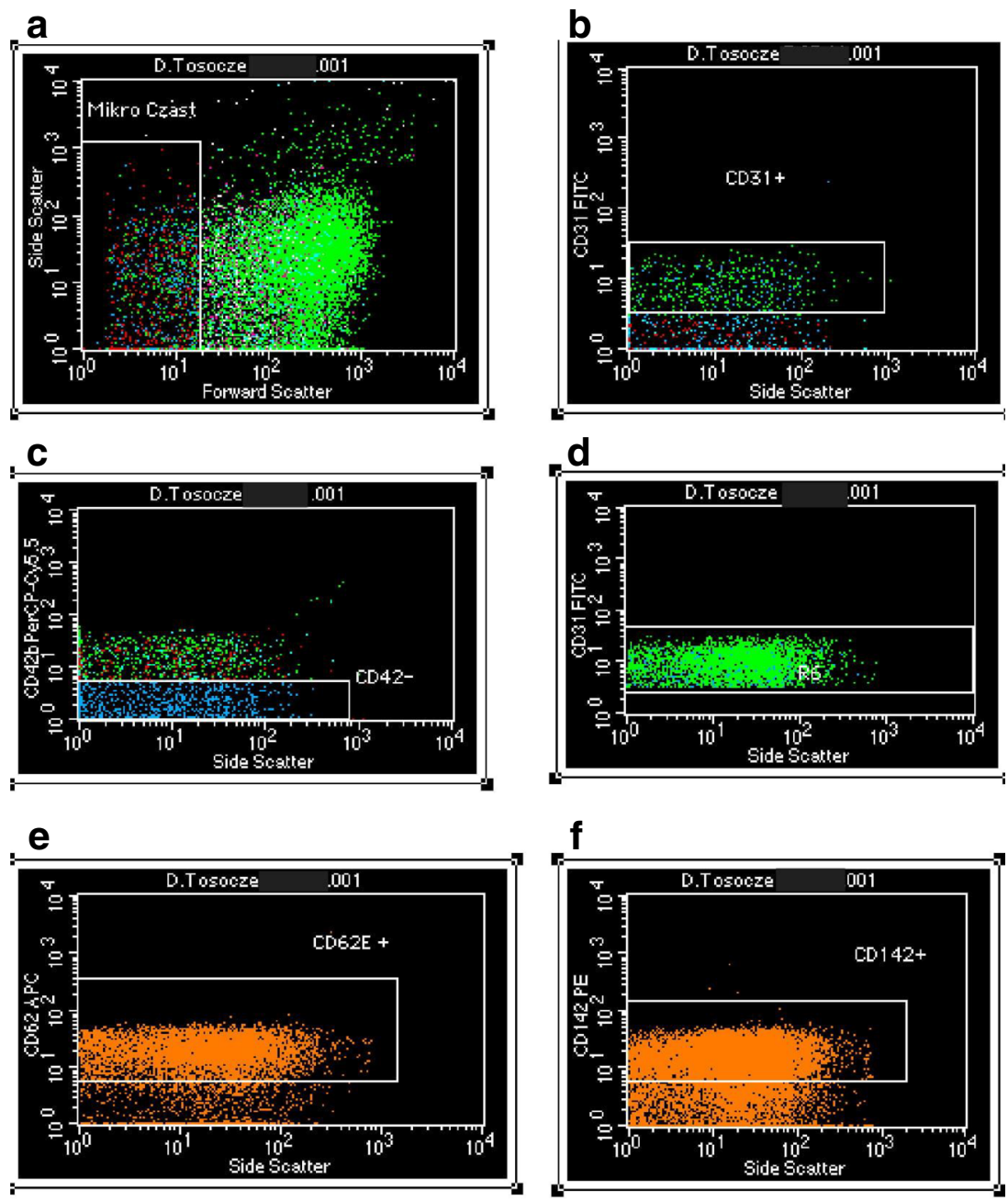
CA, USA) and included: CellWASH, FACS Lysing Solution, PBS Wash buffer, FACS Flow Sheath Fluid, FASC Lysing Solution.

\section{Vascular Endothelial Growth Factor (VEGF) and Thrombin-antithrombin Complex (TAT) Measurement by ELISA}

Blood was collected under the same conditions as described in the method of EMP enumeration by flow cytometry. The number of plasma samples was the same.

The samples were centrifuged at $1500 \mathrm{x}$ g for $15 \mathrm{~min}$ at room temperature in order to yield plasma. Sample storage time before centrifugation never exceeded $30 \mathrm{~min}$ following venipuncture. The plasma was frozen and stored at $-20^{\circ} \mathrm{C}$ until analysis. Before the assay, all samples were slowly thawed and gently vortexed by hand to resuspend. VEGF and thrombin-antithrombin complex (TAT) plasma levels were determined using an immunoenzymatic method.

To assess TAT and VEGF concentrations, IMUBIND TAT (American Diagnostica, USA) and VEGF Quantikine ELISA (R\&D Systems, USA) kits were used, respectively.

Correlations between plasma EMP levels and either plasma TAT concentration or plasma VEGF concentration were analyzed.

\section{Statistical Analysis}

Data were expressed as median, mean and standard deviation. The Shapiro-Wilk test was used to check for normal distribution of the results. To compare the levels of EMPs, TAT and VEGF between groups, the Wilcoxon Signed Rank test for dependent data was used. Correlations between EMP and TAT as well as between EMP and VEGF were assessed with the Spearman test. Statistical significance was defined by $p<$
0.05. Analyses were performed with STATISTICA 10 software and Microsoft Excel 2010.

\section{Results}

\section{Concentration of $\mathrm{TF}^{-}$EMPs in Plasma of Colon Cancer Patients Undergoing Adjuvant Chemotherapy and in Plasma of Rectal Cancer Patients Receiving Palliative Chemotherapy}

$T^{-}$EMPs were characterized by phenotype $\mathrm{CD} 31^{+} \mathrm{CD} 142^{-} \mathrm{CD} 42 \mathrm{~b}^{-}$. Colon cancer patients had statistically significantly higher concentrations of $\mathrm{TF}^{-} \mathrm{EMPs}$ before treatment $(1640 \pm 648 / \mu 1(\mathrm{p}<0.05)$ and after the 3 rd cycle of adjuvant chemotherapy $(1940 \pm 294 / \mu \mathrm{l}(\mathrm{p}<0.05)$ in comparison to the control group $(834 \pm 667 / \mu \mathrm{l})$ (Table 1$)$.

$\mathrm{TF}^{-}$EMP concentrations in RC patients were significantly higher in comparison with the control group before PC (1646 $\pm 884 / \mu 1$ vs. $834 \pm 667 / \mu 1, p<0.05)$, as well as after the 3 rd course of chemotherapy $(2087 \pm 324 / \mu 1, p<0.05)$ (Table 2$)$.

\section{Concentration of TF ${ }^{+}$EMPs in Colon Cancer Patients Undergoing Adjuvant Chemotherapy and in Rectal Cancer Patients Receiving Palliative Chemotherapy}

The $\mathrm{TF}^{+}$EMPs were the vesicles with phenotype $\mathrm{CD} 31^{+} \mathrm{CD} 62 \mathrm{E}^{+} \mathrm{CD} 142^{+} \mathrm{CD} 42 \mathrm{~b}^{-}$. Colon cancer patients had significantly higher $\mathrm{TF}^{+} \mathrm{EMP}$ concentrations before treatment $(1655 \pm 882 / \mu 1, \mathrm{p}<0.05)$ and after adjuvant chemotherapy $(1149 \pm 550 / \mu 1, \mathrm{p}<0.05)$ when compared to the control group $(688 \pm 647 / \mu \mathrm{l})$. There was no statistically significant difference in $\mathrm{TF}^{+} \mathrm{EMPs}$ concentrations in colon cancer patients before and after adjuvant chemotherapy (Table 1).

Compared to healthy subjects $(688 \pm 647 / \mu 1), \mathrm{TF}^{+} \mathrm{EMP}$ levels in rectal cancer patients were significantly higher before
Table 1 Concentrations of tissue factor-negative endothelial microparticles (TF EMPs) and tissue factor-positive endothelial microparticles (TF ${ }^{+} \mathrm{EMPs}$ ) in the plasma of colon cancer patients undergoing adjuvant chemotherapy and in the control group

\begin{tabular}{|c|c|c|c|c|}
\hline \multirow[t]{2}{*}{ Time of assessment } & \multicolumn{2}{|c|}{$\begin{array}{l}\text { EMP CD } 31^{+} / \mathrm{CD} 6 \mathrm{E}+/ \\
\left.\mathrm{CD} 142^{-} / \mathrm{CD} 42 \mathrm{~b}^{-} \text {[quantity } / \mu \mathrm{l}\right]\end{array}$} & \multicolumn{2}{|c|}{$\begin{array}{l}\text { EMP CD } 31^{+} / \mathrm{CD} 62 \mathrm{E}+/ \\
\mathrm{CD} 142^{+} / \mathrm{CD}^{2} 2 \mathrm{~b}^{-}[\text {quantity } / \mu 1]\end{array}$} \\
\hline & $\mathrm{x} \pm \mathrm{SD}$ & $\mathrm{Me}$ & $\mathrm{x} \pm \mathrm{SD}$ & $\mathrm{Me}$ \\
\hline control group & $834 \pm 667$ & 1141 & $688 \pm 647$ & 345 \\
\hline before adjuvant chemotherapy & $1640^{*} \pm 648$ & 1451 & $1655^{*} \pm 882$ & 1495 \\
\hline after 3 courses of adjuvant chemotherapy & $1940 * \pm 294$ & 2065 & $1149 * \pm 550$ & 1348 \\
\hline
\end{tabular}

CD31, CD62E - EMP surface antigens

$\mathrm{CD} 42 \mathrm{~b}$ - platelets and megakaryocyte surface antigens

$\mathrm{x}$-mean

$\mathrm{SD}$-standard deviation

$\mathrm{Me}-$ median

* - significant difference in comparison with the control group 
Table 2 Concentrations of tissue factor-negative endothelial microparticles (TF EMPs) and tissue factor-positive endothelial microparticles (TF $\left.{ }^{+} \mathrm{EMPs}\right)$ in the plasma of rectal cancer patients undergoing palliative chemotherapy and in the control group

\begin{tabular}{|c|c|c|c|c|}
\hline \multirow[t]{2}{*}{ Time of assessment } & \multicolumn{2}{|c|}{ 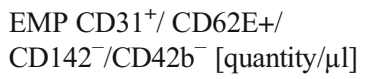 } & \multicolumn{2}{|c|}{$\begin{array}{l}\text { EMP CD } 31^{+} / \mathrm{CD} 62 \mathrm{E}+/ \\
\mathrm{CD} 142^{+} / \mathrm{CD}^{2} 4 \mathrm{~b}^{-} \text {[quantity } / \mu 1 \text { ] }\end{array}$} \\
\hline & $\mathrm{x} \pm \mathrm{SD}$ & $\mathrm{Me}$ & $\mathrm{x} \pm \mathrm{SD}$ & $\mathrm{Me}$ \\
\hline control group & $834 \pm 667$ & 1141 & $688 \pm 647$ & 345 \\
\hline before palliative chemotherapy & $1646^{*} \pm 884$ & 1771 & $1417 * \pm 643$ & 1389 \\
\hline after 3 courses of palliative chemotherapy & $2087^{*} \pm 324$ & 2023 & $1613 * \pm 231$ & 1622 \\
\hline
\end{tabular}

CD31, CD62E - EMP surface antigens

$\mathrm{CD} 42 \mathrm{~b}$ - platelets and megakaryocyte surface antigens

$\mathrm{x}-$ mean

SD -standard deviation

$\mathrm{Me}$ - median

*- significant difference in comparison with the control group treatment $(1417 \pm 643 / \mu 1, \mathrm{p}<0.05)$ and after palliative chemotherapy $(1613 \pm 231 / \mu 1, p<0.05)$. There was no statistically significant difference in $\mathrm{TF}^{+} \mathrm{EMP}$ concentrations with the cohort of rectal cancer patients before and after palliative chemotherapy (Table 2).

\section{Concentration of VEGF in Colon Cancer Patients Undergoing Adjuvant Chemotherapy and Rectal Cancer Patients Receiving Palliative Chemotherapy}

According to the analysis, VEGF concentrations in colon cancer patients were statistically significantly higher before treatment $(199.9 \pm 211.9 \mathrm{pg} / \mathrm{ml}, \mathrm{p}<0.05)$ and after the 3 rd course of adjuvant chemotherapy $(361.5 \pm 210.5 \mathrm{pg} / \mathrm{ml}, \mathrm{p}<0.05)$ when compared to the control group $(50.2 \pm 44.4 \mathrm{pg} / \mathrm{ml})$. Patients after adjuvant chemotherapy had significantly higher VEGF levels compared to baseline values $(\mathrm{p}<0.05)$ (Fig. 2).

Compared to the control group $(50.2 \pm 44.4 \mathrm{pg} / \mathrm{ml})$, rectal cancer patients had significantly higher (about 2-fold) VEGF levels before palliative chemotherapy $(112.5 \pm 88.6 \mathrm{pg} / \mathrm{ml}, \mathrm{p}$ $<0.05)$ and after palliative chemotherapy $(278.8 \pm 209 \mathrm{pg} / \mathrm{ml}$, $\mathrm{p}<0.05$ ) (Fig. 3).

\section{Concentration of TAT in Colon Cancer Patients Undergoing Adjuvant Chemotherapy and Rectal Cancer Patients Receiving Palliative Chemotherapy}

The mean concentration of TAT in colon cancer patients before treatment $(2.46 \pm 2.15 \mathrm{ng} / \mathrm{ml})$ was significantly higher when compared to the control group $0.77 \pm 0.57 \mathrm{ng} / \mathrm{ml}, \mathrm{p}<$ 0.05) (Fig. 4).

After 3rd course of adjuvant chemotherapy, TAT levels $(12.83 \pm 2.22 \mathrm{ng} / \mathrm{ml})$ were significantly higher when compared to both pre-chemotherapy concentrations $(2.46 \pm 2.15$ $\mathrm{ng} / \mathrm{ml}, \mathrm{p}<0.05)$ and the control group $(0.77 \pm 0.57 \mathrm{ng} / \mathrm{ml}, \mathrm{p}$ $<0.05$ ) (Fig. 4).
The mean TAT concentration in rectal cancer patients before treatment was significantly higher than in healthy subjects $(1.82 \pm 1.49 \mathrm{ng} / \mathrm{ml}$ vs. $0.77 \pm 0.57 \mathrm{ng} / \mathrm{ml}, \mathrm{p}<0.05)$. Rectal cancer patients had significantly higher TAT levels after the 3rd course of palliative chemotherapy $(15.3 \pm 6.63 \mathrm{ng} / \mathrm{ml}) \mathrm{com}$ pared to baseline values $(1.82 \pm 1.49 \mathrm{ng} / \mathrm{ml}, \mathrm{p}<0.05)$ and the control group $(0.77 \pm 0.57 \mathrm{ng} / \mathrm{ml}, \mathrm{p}<0.05)$ (Fig. 5).

\section{Correlation Between the Levels of EMPs and TAT as well as Between EMPs and VEGF Levels in Colon Cancer and Rectal Cancer Patients Undergoing Adjuvant Chemotherapy and Palliative Chemotherapy}

There was no statistically significant correlation between $\mathrm{TF}^{+}$EMPs and TAT levels in $\mathrm{CC}$ patients before treatment $(\mathrm{r}=-0.626, \mathrm{p}=0.096)$ and after $\mathrm{AC}(\mathrm{r}=0.047, \mathrm{p}=0.91)$. No significant correlation was demonstrated also between $\mathrm{TF}^{+} \mathrm{EMPs}$ and TAT concentrations in rectal cancer patients before treatment $(r=-0.309, p=0.881)$ and after palliative

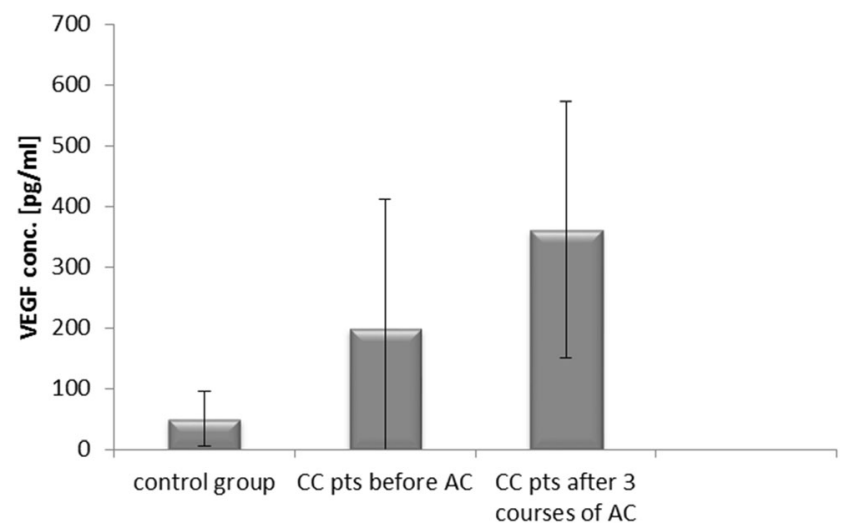

Fig. 2 Vascular endothelial growth factor (VEGF) concentrations in colon cancer (CC) patients (pts) undergoing adjuvant chemotherapy (AC) and in the control group 


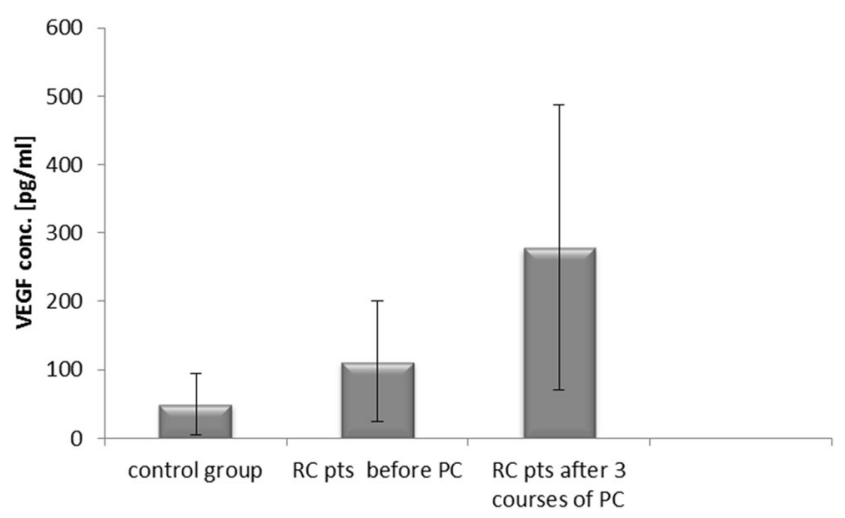

Fig. 3 Vascular endothelial growth factor (VEGF) concentrations in rectal cancer (RC) patients (pts) undergoing palliative chemotherapy (PC) and in the control group

chemotherapy $(r=-0.058, p=0.881)$. Similarly, no correlation was found between TF EMPs and VEGF concentrations in colon cancer patients before treatment $(r=-0.108, \mathrm{p}=0.798)$ and after adjuvant chemotherapy $(\mathrm{r}=0.238, \mathrm{p}=0.57)$. However, a significant negative correlation was demonstrated between $\mathrm{TF}^{+}$EMPs and VEGF levels before treatment $(\mathrm{r}=$ $0.266, p=0.487)$ and after palliative chemotherapy $(r=-$ $0.811, \mathrm{p}=0.007)$.

\section{Discussion}

A number of abnormalities in blood coagulation in association with cancer have been demonstrated, including elevated fibrinogen, thrombin generation, enhanced expression of TF and cancer procoagulant [26]. An imbalance between activators and inhibitors of the hemostatic system is observed, which may contribute not only to increased prothrombotic tendency but also to tumor invasion, progression and metastasis [27-32]. A growing body of evidence indicates that different forms of anticancer treatment affect the hemostatic system in cancer patients $[8,33-36]$.
Circulating MPs contribute to inflammatory responses, vascular remodeling, angiogenesis and apoptosis, and are involved in atherothrombosis [37-39]. Increased levels of circulating MPs have been reported in a wide range of diseases connected with thrombotic risk. Cancer patients appear to have elevated levels of procoagulant MPs compared to healthy controls [40-42]. Cancer-related hypercoagulability may in part result from elevated levels of circulating microparticle-bound TF (MPTF). Among several subgroups of MPs, platelet microparticles (PMPs) and EMPs may be of special importance $[20,43]$.

EMPs may offer a potentially unique set of biomarkers of thrombotic disorders, including cancer-related thrombosis [40, 42, 44]. In fact, the assessment of EMP levels has been receiving increased attention as a possible diagnostic/ prognostic indicator for thromboembolism [45]. Chirinos et al. [46] reported significantly increased concentrations of EMPs during acute VTE. Another study revealed that the levels of circulating platelet microparticle-associated TF (PMPTF) and EMP-associated TF (EMPTF) were significantly increased in comparison to other MPTF in recurrent deep venous thrombosis (DVT) [47]. Cancer patient MPTF levels and associated activities were analyzed by several groups of investigators. Tesselaar et al. [44] found increased levels of TF-positive MPs in pancreatic and breast adenocarcinoma patients compared with controls. Hron et al. [40] reported a two-fold higher level of TFpositive MPs in the plasma of advanced CRC compared to healthy subjects. Khorana et al. [41] described that the activity of TF-positive MPs may be predictive of VTE in pancreatic cancer patients. Thaler et al. [42] investigated the predictive value of MPTF activity in terms of mortality and VTE occurrence in pancreatic, gastric, colorectal and brain cancer patients. MPTF activity was not associated with subsequent VTE incidence in any of the four groups of patients, while a strong association between mortality and MPTF activity was demonstrated exclusively in pancreatic cancer patients.
Fig. 4 Thrombin-antithrombin complex (TAT) concentrations in colon cancer (CC) patients (pts) undergoing adjuvant chemotherapy $(\mathrm{AC})$ and in the control group

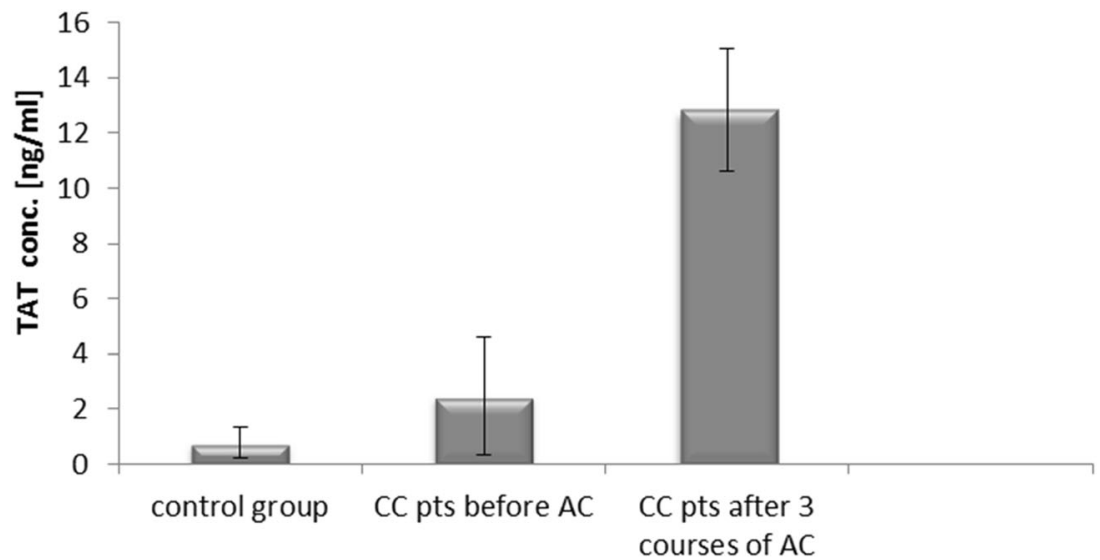


Fig. 5 Thrombin-antithrombin complex (TAT) concentrations in rectal cancer $(\mathrm{RC})$ patients (pts) undergoing palliative chemotherapy $(\mathrm{PC})$ and in the control group

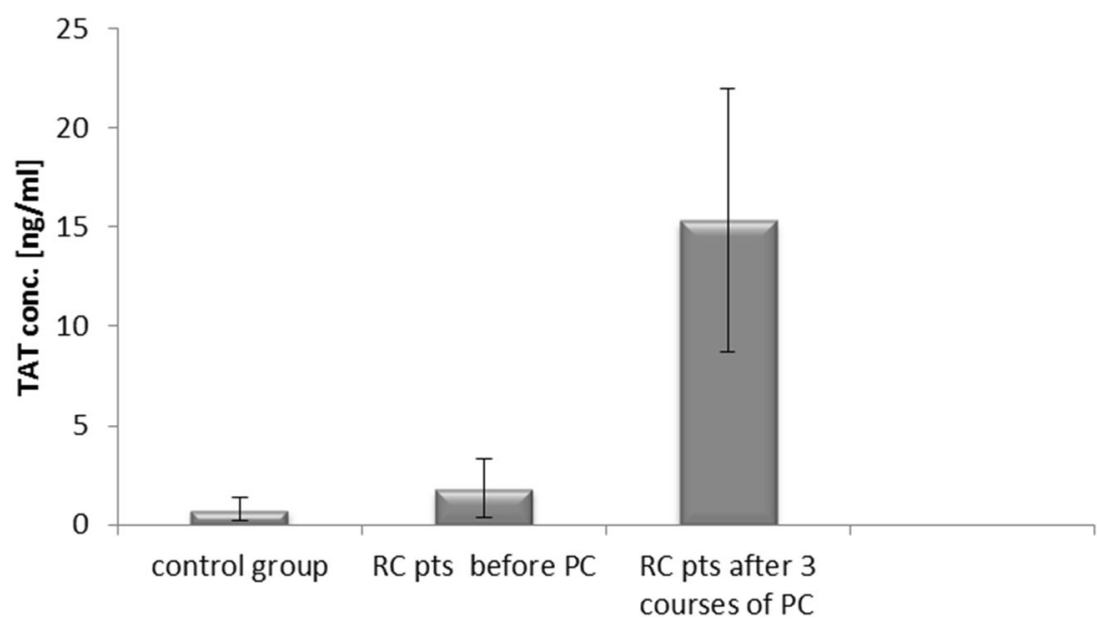

The current study analyzes EMPs, TAT and VEGF levels in CRC patients undergoing adjuvant or palliative chemotherapy. Thrombin-antithrombin complexes have been used as a well-established marker for thrombin generation [48], where higher TAT levels correspond with enhanced TF expression in pancreatic cancer patients [49]. Increased TAT concentrations were demonstrated in CC patients [50]. In the present study significantly higher concentrations of TAT were observed in CRC patients in comparison to healthy subjects, both before treatment and after the 3rd course of chemotherapy. Elevated TAT in CRC patients treated with adjuvant or palliative chemotherapy might suggest an influence of the treatment on blood coagulation activation. There does not appear to be a significant correlation between EMPs and TAT levels in CRC patients. Our results are in accordance with findings of Tesselaar et al. [51], who found only a weak correlation between MPTF activity and TAT levels in cancer patients. Lechner et al. [52] reported marginal TF expression on EMPs and found that thrombin generation induced by EMPs was independent of TF. The study also suggested that the release of EMPs does not contribute to hemostatic abnormalities in cancer patients.

Vascular endothelial growth factor is the major factor stimulating tumor angiogenesis [53-55]. Expression of VEGF correlates with poor prognosis and metastatic dissemination in a wide variety of human malignancies, e.g., lung [51], gastric [56] and colorectal [57] cancer. It has been suggested that serum VEGF levels could be a prognostic marker in CRC patients [58]. We observed significantly higher VEGF levels in CRC patients when compared to healthy subjects, as well as increased VEGF levels in cancer patients undergoing chemotherapy in comparison to patients before treatment. Adjuvant and palliative chemotherapy may contribute to increased VEGF concentrations in cancer patients, which has been observed by other investigators. Breast cancer patients experienced an increasing trend in plasma VEGF levels during chemotherapy, and the types of treatment regimens may differentially effect circulating VEGF levels [59]. In our study no significant correlation was found between EMPs and free VEGF concentrations in CRC patients undergoing adjuvant or palliative chemotherapy. Other investigators reported a correlation between EMPs and VEGF concentrations in cancer patients treated with VEGF inhibitors [60]. However, our patients underwent chemotherapy without antiangiogenic agents. It is noteworthy that EMPs may stimulate angiogenesis via molecules other than VEGF, e.g. TGF- $\beta$, proteolytic enzymes [61], sphingomyelin [62] and micro-RNA [63]. This points to a more complex interplay among various proangiogenic factors at a tumor site, which might not necessarily be reflected by the concentration of free VEGF in the plasma.

\section{Conclusions}

CRC patients exhibit elevated TAT and VEGF levels, which tend to increase during the course of chemotherapy. EMPs may also contribute to the observed changes. However, additional studies performed on a larger group of patients and employing more parameters reflecting hemostasis and angiogenesis are warranted.

Authors' Contributions Marek Z. Wojtukiewicz - concept of the study, supervision, interpreting results, writing draft of the manuscript, approval of the final manuscript. Marta Myśliwiec - performing experiments, writing the manuscript, literature searching, approval of the final manuscript. Ewa Sierko - writing draft of the manuscript, approval of the manuscript. Monika Sobierska - collecting material, interpreting the results, performing experiments, approval of the manuscript. Joanna Kruszewska - performing experiments, literature searching, approval of the manuscript. Alina Lipska - performing experiments. Piotr Radziwon - supervision on the experiments, approval of the final manuscript. Stephanie C. Tucker - writing of the final version of the manuscript, approval of the final manuscript. Kenneth V. Honn - writing final version of the manuscript, approval of the final manuscript. 
Funding Information This work was supported by Medical University of Bialystok, Poland.

Data Availability All data generated or analyzed during this study are included in this published article.

\section{Compliance with Ethical Standards}

Conflict of Interest The authors declare no conflict of interest.

Ethics Approval and Consent to Participate The study protocol was approved by the Bioethics Committee of Medical University in Bialystok, Poland, according to the Guidelines for Good Clinical Practice. A written consent was obtained from each participant.

\section{Consent for Publication Not applicable.}

Open Access This article is licensed under a Creative Commons Attribution 4.0 International License, which permits use, sharing, adaptation, distribution and reproduction in any medium or format, as long as you give appropriate credit to the original author(s) and the source, provide a link to the Creative Commons licence, and indicate if changes were made. The images or other third party material in this article are included in the article's Creative Commons licence, unless indicated otherwise in a credit line to the material. If material is not included in the article's Creative Commons licence and your intended use is not permitted by statutory regulation or exceeds the permitted use, you will need to obtain permission directly from the copyright holder. To view a copy of this licence, visit http://creativecommons.org/licenses/by/4.0/.

\section{References}

1. Trousseau A (1865) Phlegmasia alba dolens. Clinique Medicale de 1'Hotel-Dieu de Paris: The Sydenham Society, pp 94-96

2. Khorana AA, Francis CW, Culakova E, Fisher RI, Kuderer NM, Lyman GH (2006) Thromboembolism in hospitalized neutropenic cancer patients. J Clin Oncol 24:484-490

3. Sallah S, Wan JY, Nguyen NP (2002) Venous thrombosis in patients with solid tumors: determination of frequency and characteristics. Thromb Haemost 87:575-579

4. Sørensen HT, Mellemkjaer L, Olsen JH, Baron JA (2000) Prognosis of cancers associated with venous thromboembolism. N Engl J Med 21:343: 1846-1850

5. Khorana AA, Francis CW, Culakova E, Kuderer NM, Lyman GH (2007) Thromboembolism is a leading cause of death in cancer patients receiving outpatient chemotherapy. J Thromb Haemost 5: 632-634

6. Lee AY, Levine MN (2003) Venous thromboembolism and cancer: risks and outcomes. Circulation 17(23 Suppl 1):I17-I21 107(

7. Rees PA, Clouston HW, Duff S, Kirwan CC (2018) Colorectal cancer and thrombosis. Int J Colorectal Dis 33:105-108

8. Heit JA, Silverstein MD, Mohr DN, Petterson TM, O'Fallon WM, Melton LJ 3rd (2000) Risk factors for deep vein thrombosis and pulmonary embolism: a population-based case-control study. Arch Intern Med 27;160:809-815

9. Folkman J (1971) Tumor angiogenesis: therapeutic implications. N Engl J Med 285:1182-1186

10. Wojtukiewicz MZ, Sierko E, Klement P, Rak J (2001) The Hemostatic System and Angiogenesis in Malignancy. Neoplasia $3: 371-384$
11. Abdulkadir SA, Carvalhal GF, Kaleem Z et al (2000) Tissue factor expression and angiogenesis in human prostate carcinoma. Hum Pathol 31:443-447

12. Folkman J (1996) Tumor angiogenesis and tissue factor. Nat Med 2:167-168

13. Wojtukiewicz MZ, Sierko E, Rak J (2004) Contribution of the Hemostatic System to Angiogenesis in Cancer. Semin Thromb Hemost 30:5-20

14. Yan SF, Zou YS, Gao Y, Zhai C, Mackman N, Lee SL, Milbrandt J, Pinsky D, Kisiel W, Stern D (1998) Tissue factor transcription driven by Egr-1 is a critical mechanism of murine pulmonary fibrin deposition in hypoxia. Proc Natl Acad Sci USA 95:8298-8303

15. Shweiki D, Itin A, Soffer D, Keshet E (1992) Vascular endothelial growth factor induced by hypoxia may mediate hypoxia-initiated angiogenesis. Nature 359:843-845

16. Flak B, Wawrzyniec K, Kwiatek S, Kawczyk-Krupka A, Czuba Z, Sieroń-Stołtny K, Sieroń A (2013) Vascular endothelial growth factor (VEGF) as a marker for cancer progression - a review. Acta Bio-Optica et Informatica Medica Inżynieria Biomedyczna 19:4: 205-209

17. Sierko E, Sokół M, Wojtukiewicz MZ (2015) Mikropęcherzyki pochodzenia śródbłonkowego (EMP) rola w fizjologii i patologii. Postępy Hig Med Dosw 69:925-932

18. Nomura S, Niki M, Nisizawa T, Tamaki T, Shimizu M (2015) Microparticles as Biomarkers of Blood Coagulation in Cancer. Biomark Cancer 7:51-6

19. Morel O, Toti F, Hugel B et al (2006) Procoagulant microparticles: disrupting the vascular homeostasis equation? Arteriosclerosis. Thromb Vasc Biol 26:2594-2604

20. Markiewicz M, Richard E, Marks N, Ludwicka-Bradley A (2013) Impact of endothelial microparticles on coagulation, inflammation, and angiogenesis in age-related vascular diseases. J Aging Res 2013:734509. https://doi.org/10.1155/2013/734509

21. Amabile N, Heiss C, Real WM, Minasi P, McGlothlin D, Rame EJ, Grossman W, De Marco T, Yeghiazarians Y (2008) Circulating endothelial microparticle levels predict hemodynamic severity of pulmonary hypertension. Am J Respir Crit Care Med 177:12681275

22. Jimenez JJ, Jy W, Mauro LM, Soderland C, Horstman LL, Ahn YS (2003) Endothelial cells release phenotypically and quantitatively distinct microparticles in activation and apoptosis. Thromb Res 109:175-180

23. Silva J, Garcia V, Rodriguez M, Compte M, Cisneros E, Veguillas P, Garcia JM, Dominguez G, Campos-Martin Y, Cuevas J, Peña C, Herrera M, Diaz R, Mohammed N, Bonilla F (2012) Analysis of exosome release and its prognostic value in human colorectal cancer. Genes Chromosomes Cancer 51:409-418

24. Stec M, Baj-Krzyworzeka M, Baran J, Weeglarczyk K, Zembala M, Barbasz J, Szczepanik A, Zembala M (2015) Isolation and characterization of circulating micro(nano)vesicles in the plasma of colorectal cancer patients and their interactions with tumor cells. Oncol Rep 34:2768-2775

25. Goon PKY, Lip GYH, Boos CJ, Stonelake PS, Blann AD (2006) Circulating endothelial cells, endothelial progenitor cells, and endothelial microparticles in cancer. Neoplasia 8:79-88

26. Pabinger I, Thaler J, Ay C (2013) Biomarkers for prediction of venous thromboembolism in cancer. Blood 122:2011-2018

27. Wojtukiewicz MZ, Sierko E, Kisiel W (2007) The role of hemostatic system inhibitors in malignancy. Semin Thromb Hemost 33: 621-642

28. Wojtukiewicz MZ, Hempel D, Sierko E, Tucker SC, Honn KV (2016) Thrombin-unique coagulation system protein with multifaceted impacts on cancer and metastasis. Cancer Metastasis Rev 35: 213-233 
29. Sierko E, Wojtukiewicz MZ, Zimnoch L (2010) Expression of TFPI in breast cancer and colon cancer. Thromb Haemost 103: 198-204

30. Wojtukiewicz MZ, Sierko E, Zimnoch L (2003) Immunohistochemical localization of TFPI-2 in human tumor tissue. Thromb Haemost 90:140-146

31. Wojtukiewicz MZ, Hempel D, Sierko E, Tucker ST, Honn KV (2015) Protease-activated receptors (PARs) - biology and role in cancer invasion and metastasis. Cancer Metast Rev 34:775-796

32. Wojtukiewicz MZ, Hempel D, Sierko E, Tucker SC, Honn KV (2019) Endothelial Protein C Receptor (EPCR), Protease Activated Receptor-1 (PAR-1) and their interplay in cancer growth and metastatic dissemination.\&nbsp;Review. Cancers (Basel) 8:11. https://doi.org/10.3390/cancers11010051

33. Falanga A, Marchetti M (2012) Anticancer treatment and thrombosis. Thromb Res Mar 129:353-359

34. Haddad TC, Greeno EW (2006) Chemotherapy-induced thrombosis. Thromb Res 118:555-568

35. Seng S, Liu Z, Chiu SK, Proverbs-Singh T, Sonpavde G, Choueiri TK, Tsao CK, Yu M, Hahn NM, Oh WK, Galsky MD (2012) Risk of venous thromboembolism in patients with cancer treated with Cisplatin: a systematic review and meta-analysis. J Clin Oncol 10;30:4416-4426

36. Swystun LL, Mukherjee S, Liaw PC (2011) Breast cancer chemotherapy induces the release of cell-free DNA, a novel procoagulant stimulus. J Thromb Haemost 9:2313-2321

37. Hugel B, Martínez MC, Kunzelmann C, Freyssinet JM (2005) Membrane microparticles: two sides of the coin. Physiology (Bethesda) 20:22-27

38. Morel O, Toti F, Hugel B, Freyssinet JM (2004) Cellular microparticles: a disseminated storage pool of bioactive vascular effectors. Curr Opin Hematol 11:156-164

39. VanWijk MJ, VanBavel E, Sturk A, Nieuwland R (2003) Microparticles in cardiovascular diseases. Cardiovasc Res 59: 277-287

40. Hron G, Kollars M, Weber H, Sagaster V, Quehenberger P, Eichinger S, Kyrle PA, Weltermann A (2007) Tissue factorpositive microparticles: cellular origin and association with coagulation activation in patients with colorectal cancer. Thromb Haemost 97:119-123

41. Khorana AA, Francis CW, Menzies KE, Wang JG, Hyrien O, Hathcock J, Mackman N, Taubman MB (2008) Plasma tissue factor may be predictive of venous thromboembolism in pancreatic cancer. J Thromb Haemost 6:1983-1985

42. Thaler J, Ay C, Mackman N, Bertina RM, Kaider A, Marosi C, Key NS, Barcel DA, Scheithauer W, Kornek G, Zielinski C, Pabinger I (2012) Microparticle-associated tissue factor activity, venous thromboembolism and mortality in pancreatic, gastric, colorectal and brain cancer patients. J Thromb Haemost 10:1363-1370

43. Wang M, Fu Y, Xu L, Xiao L, Yue Y, Liu S, Huang Q, Li S, Li Y (2018) Diagnostic value of platelet-derived microparticles in pulmonary thromboembolism: A population-based study. Exp Ther Med 16:3099-3106

44. Tesselaar ME, Romijn FP, Van Der Linden IK, Prins FA, Bertina RM, Osanto S (2007) Microparticle-associated tissue factor activity: a link between cancer and thrombosis? J Thromb Haemost 5: 520-527

45. Enjeti AK, Lincz LF, Seldon M (2007) Detection and measurement of microparticles: an evolving research tool for vascular biology. Semin Thromb Hemost 33:771-779

46. Chirinos JA, Heresi GA, Velasquez H, Jy W, Jimenez JJ, Ahn E, Horstman LL, Soriano AO, Zambrano JP, Ahn YS (2005) Elevation of endothelial microparticles, platelets, and leukocyte activation in patients with venous thromboembolism. J Am Coll Cardiol 45:1467-1471
47. Ye R, Ye C, Huang Y, Liu L, Wang S (2012) Circulating tissue factor positive microparticles in patients with acute recurrent deep venous thrombosis. Thromb Res 130:253-258

48. Deguchi K, Noguchi M, Yuwasaki E, Endou T, Deguchi A, Wada H, Murashima S, Nishikawa M, Shirakawa S, Tanaka K, Kusagawa M (1991) Dynamic fluctuations in blood of thrombin/antithrombin III complex (TAT). Am J Hematol 38:86-89

49. Haas SL, Jesnowski R, Steiner M, Hummel F, Ringel J, Burstein C, Nizze H, Liebe S, Löhr JM (2006) Expression of tissue factor in pancreatic adenocarcinoma is associated with activation of coagulation. World J Gastroenterol 12:4843-4849

50. van Duijnhoven EM, Lustermans FA, van Wersch JW (1993) Evaluation of the coagulation/fibrinolysis balance in patients with colorectal cancer. Haemostasis 23:168-172

51. Tesselaar ME, Romijn FP, van der Linden IK, Bertina RM, Osanto S (2009) Microparticle-associated tissue factor activity in cancer patients with and without thrombosis. J Thromb Haemost 7: 1421-1423

52. Lechner D, Weltermann A (2008) Chemotherapy-induced thrombosis: a role for microparticles and tissue factor? Semin Thromb Hemost 34:199-203

53. Ferrara N (2001) Role of vascular endothelial growth factor in regulation of physiological angiogenesis. Am J Physiol Cell Physiol 280:C1358-C1366

54. Sakurai T, Kudo M (2011) Signaling pathways governing tumor angiogenesis. Oncology 81(Suppl 1):24-29

55. Volm M, Koomägi R, Mattern J (1999) PD-ECGF, bFGF, and VEGF expression in non-small cell lung carcinomas and their association with lymph node metastasis. Anticancer Res 19:651-655

56. Seo HY, Park JM, Park KH, Kim SJ, Oh SC, Kim BS, Kim YH, Kim JS (2010) Prognostic significance of serum vascular endothelial growth factor per platelet count in unresectable advanced gastric cancer patients. Jpn J Clin Oncol 40:1147-1153

57. Ferroni P, Spila A, Martini F, D'Alessandro R, Mariotti S, Del Monte G, Graziano P, Buonomo O, Guadagni F, Roselli M (2005) Prognostic value of vascular endothelial growth factor tumor tissue content of colorectal cancer. Oncology 69:145-153

58. Chin KF, Greenman J, Gardiner E, Kumar H, Topping K, Monson J (2000) Pre-operative serum vascular endothelial growth factor can select patients for adjuvant treatment after curative resection in colorectal cancer. Br J Cancer 83:1425-1431

59. Ng T, Phey XY, Yeo HL, Shwe M, Gan YX, Ng R, Ho HK, Chan A (2018) Impact of Adjuvant Anthracycline-Based and TaxaneBased Chemotherapy on Plasma VEGF Levels and Cognitive Function in Breast Cancer Patients: A Longitudinal Study. Clin Breast Cancer 18:e927-e937

60. Neves KB, Rios FJ, Jones R, Evans TRJ, Montezano AC, Touyz RM (2019) Microparticles from vascular endothelial growth factor pathway inhibitor-treated cancer patients mediate endothelial cell injury. Cardiovasc Res 115:978-988

61. Giusti I, Delle Monache S, Di Francesco M, Sanità P, D'Ascenzo S, Gravina GL, Festuccia C, Dolo V (2016) From glioblastoma to endothelial cells through extracellular vesicles: messages for angiogenesis. Tumour Biol 37:12743-12753

62. Kim CW, Lee HM, Lee TH, Kang C, Kleinman HK, Gho YS (2002) Extracellular membrane vesicles from tumor cells promote angiogenesis via sphingomyelin. Cancer Res 62:6312-6317

63. Kosaka N, Yoshioka Y, Fujita Y, Ochiya T (2016) Versatile roles of extracellular vesicles in cancer. J Clin Invest 126:1163-1172

Publisher's note Springer Nature remains neutral with regard to jurisdictional claims in published maps and institutional affiliations. 